Contents - continued from outside back cover]

J. I. OLAIFA, 0. O. ORAFIDIYA,

O. O. FANIRAN and A. O. ADENUGA

B. M. CHANDRA SHEKAR,

K. D. REDDY, B. U. SINGH and D.D. R. REDDY

\section{B. COULIBALY}

G. O. EZEIFEKA, J. U. UMOH,

C. D. EZEOKOU and N. E. GOMWALK

F. BETTARINI, G. E. BORGONOVI,

T. FIORANI, I. GAGLIARDI,

V. CAPRIOLI, P. MASSARDO,

J.I. J. OGOCHE, A. HASSANALI,

E. NYANDAT and A. CHAPYA

P. K. ATTAH and H. F. VAN EMDEN

K. DAKSHAYANI, J. S. BENTUR and M. B. KALODE

P. G. TOKRO, R. BROSSUT

et L. SRENG

Instructions to authors

Author checklist
69 Formulation of a locust lotion concentrate for grasshopper control

77 Antixenosis component of resistance to com planthopper, Peregrinus maidis (Ashmead) in sorghum

Les dolichopodidae (Diptera) dans le controle biologique de certaines insectes nuisibles de ecosystemes forestiers

89 Experimental transmission of Ife vinus by Aedes aegypti mosquitoes

93 Antiparasitic compounds from East African plents: Isolation and biological activity of anonaine, matricarianol, canthin-6-one and caryophyllene oxide

101 The susceptibility to malathion of Metopolophium dirhodum on two wheat species at two growth stages, and the effect of plant growth regulators on this susceptibility

107 Nature of resistance in rice varieties against leaffolder Cnaphalocrocis medinalis (Guence)

115 Mise en evidence de la pheromone sexuelle chez les femelles de Blattella germanica $\mathbf{L}$. 


\section{Insect Science and its Application}

The International Journal of Tropical Insect Science

VOLUME 14 NUMBER 1

1993

\section{CONTENTS}

\section{CISHAHAYO}

A. A. AL-TAWEEL, M. S. H. AHMED,

M. A. SHAWKIT and M. J. NASSER

K. N. SINGH and G. C. SACHAN

S. NOKOE, P. B. CAPSTICK,

A. A. LATIF and D. K. PUNYUA

N. SIVARAMI REDDY, T. PAVAN KUMAR, P. MURALI MOHAN and K. SASIRA BABU

D. BOUCHARD, A. OUEDRAOGO et

G. BOIVIN

I. ANIEDU, M. J. MUTINGA and

C. M. MUTERO

A. M. ALGHALI

A. M. ALGHALI

J. ALLOTEY and J. G. MORRIS
Research Articles

1 Résistance aux thrips et correlations caractèrespopulations

7 Effects of sublethal doses of gamma radiation on the mating ability and spermatophore transfer of Ephestia cautella (Lepidoptera: Pyralidae)

11 Spodoptera litura male moth catches in pheromone traps and their relationship with oviposition in groundnut field at Pantnagar, India

15 Derivation of an index for assessing the resistance of zebu cattle to Rhipicephalus appendiculatus Neumann (Acarina: Ixodidae)

21 Photoperiodic implications on the pupal ecdysis in the silkworm, Bombyx mori L. (PM x NB4D2)

31 Impact de la coupe des tiqes du mil sur les larves diapausantes de Coniesta (Acigona) ignefusalis (Lepidoptera: Pyralidae)

39 Vertical estimates of survivorship of larvae and pupae of Anopheles gambiae Giles complex in Baringo District, Kenya

49 Intercropping as a component in insect pest management for grain cowpea, Vigna unguiculata Walp. production in Nigeria

55 The effects of some agrometeorological factors on fluctuations of the legume pod borer, Maruca testulalis Geyer (Lepidoptera: Pyralidae), on two cowpea varieties in Nigeria

61 Biology of Cathartus quadricollis Guerin-Meneville (Coleoptera: Silvanidae) on some selected food media

[continued on inside back cover

Indexed/Abstracted in

ISSN 0191-9040

Current Contents, CABS, C. A. B. International, BIOSIS, The African Book Publishing Record 